\title{
Prevalence of and Risk Factors for Listeria Species on Dairy Farms
}

\author{
M. J. Vilar, E. Yus, M. L. Sanjuán, F. J. Diéguez, and J. L. Rodríguez-Otero' \\ Instituto de Investigación y Análisis Alimentarios, Universidad de Santiago de Compostela, Facultad de Veterinaria, \\ Campus Universitario s/n. 27002, Lugo, Spain
}

\begin{abstract}
This cross-sectional study determined the prevalence of Listeria spp. in bulk-tank milk on dairy farms in the region of Galicia in northwest Spain. The aim was to identify management practices associated with the presence of Listeria spp. and possible effects on milk hygienic quality. A total of 98 farms was randomly selected on the basis of an expected prevalence of $6.5 \%$ for Listeria monocytogenes from 20,107 dairy farms in the region. Bulk-tank milk samples were obtained from 98 farms, fecal samples from lactating cows from 97 farms, and silage samples from 83 farms. Listeria monocytogenes was detected in 6.1, 9.3, and $6.0 \%$ of these samples, respectively. Statistical analyses confirmed the relationship between low silage quality (as indicated by high $\mathrm{pH}$ ) and presence of Listeria spp. in silage (29.5 vs. $6.2 \%$ for $\mathrm{pH}$ above or below 4.5, respectively). Only milking system [tie-stall systems $(28.6 \%)$ vs. parlor milking $(10 \%)]$ and inadequately controlled milking order [yes (32.0\%) vs. no (10.7\%)] had statistically significant effects on management practices for increasing the risk of Listeria contamination of bulk-tank milk.
\end{abstract}

Key words: Listeria spp., prevalence, risk factor, dairy farm

\section{INTRODUCTION}

The Listeria species are gram-positive, motile, intracellular, facultative anaerobes (Cooper and Walker, 1998; Winter et al., 2004). The genus includes Listeria monocytogenes, Listeria innocua, Listeria welshimeri, Listeria seeligeri, Listeria ivanovii (ssp. ivanovii and londoniensis); the taxonomic status of Listeria grayi, Listeria murrayi, and Listeria denitrificans is uncertain (Vázquez-Boland et al., 2001).

Listeria monocytogenes is included in the World Health Organization list of foodborne pathogens (WHO, 2002), and is the most important Listeria species in terms of public health risk and frequency of appearance

Received March 21, 2007.

Accepted July 31, 2007.

${ }^{1}$ Corresponding author: jlrotero@usc.es in foodstuffs (Fenlon and Wilson, 1989). Listeria seeligeri and $L$. ivanovii may be pathogenic in humans (Wiedmann, 2003).

Listeria monocytogenes is ubiquitously present in diverse environments including water, grass, silage, decomposing organic matter, soil, and feces (Hassan et al., 2001). It has a high capacity for persistence under adverse conditions, surviving at refrigeration temperatures and over a wide range of $\mathrm{pH}$ (Low and Donachie, 1997). Both humans and diverse wild and domestic animals may be asymptomatic carriers of $L$. monocytogenes, which is widely present in the feces of cattle, pigs, chickens, turkeys, ducks, crustaceans, and flies. Similarly, cattle may shed these bacteria in milk over long periods without showing any symptoms of disease (Low and Donachie, 1997). Listeria monocytogenes can be pathogenic for animals, and the development of clinical listeriosis was associated with stress (Cooper and Walker, 1998). The principal source of infection for ruminants is spoiled silage (Low and Donachie, 1997; Vázquez-Boland et al., 2001; Wiedmann, 2003), although it may come from contaminated water or feed contaminated by avian or insect vectors (Cooper and Walker, 1998).

Listeria monocytogenes may reach bulk tanks as a result of exogenous contamination via the milking equipment, because of fecal contamination during milking, or, less frequently, by an intramammary route following generalized asymptomatic infection or mastitis (Cooper and Walker, 1998; Hassan et al., 2001; Winter et al., 2004).

The aims of the present study were to determine the prevalence of Listeria species in on-farm bulk tanks, to identify management practices associated with the presence of Listeria species in bulk tanks, and to assess the possible influence of Listeria species on milk hygienic quality.

\section{MATERIALS AND METHODS}

\section{Study Design}

This was a cross-sectional study carried out in 2005 . Ninety-eight dairy farms were randomly selected in Galicia (northwest Spain), a region accounting for $40 \%$ of Spain's total milk production. The number of farms in- 
cluded was calculated from 20,107 dairy farms in Galicia (Instituto Galego de Estatística, 2005) using the following assumptions: 1 ) the expected prevalence of $L$. monocytogenes was 6.5\% (Van Kessel et al., 2004), 2) the level of confidence was $95 \%$, and 3) the acceptable level of error in the prevalence estimate was $5 \%$. All calculations were done with the software package WINEPI (Carmelo Ortega, Zaragoza, Spain).

The mean number of animals per herd was 61.3 (8 to $480, \mathrm{SD}=67.1$, and the mean number of lactating cows was 35.0 ( 4 to $260, \mathrm{SD}=39.3$ ). Of the 98 farms, $41.2 \%$ had free-stall housing with a milking parlor, and the remaining $58.8 \%$ had tie-stall housing with pipeline $(43.3 \%)$ or bucket (15.5\%) milking.

\section{Data Collection: Questionnaire}

Each farmer was interviewed on the farm at the time of sample collection and $\mathrm{pH}$ determination using a questionnaire about the following farm characteristics and aspects of management; however, some of these aspects were observed directly:

1) Silage storage: in a concrete-lined bunker silo, in an unlined trench silo, or in individual bags.

2) General housing conditions: ventilation and cleaning, including cleaning of walkways, stalls/bedding, and animals.

3) Milking system: milking parlor, pipeline tie-stall milking, or bucket tie-stall milking.

4) Milking procedure: identification of animals with mastitis, milking order (first: healthy cows, second: cows with subclinical mastitis, and finally, cows with clinical mastitis), predipping, forestripping, and checks to confirm that cows lie down after milking.

Somatic cell counts and bacterial counts (BC) in bulktank milk recorded for each farm as assessed monthly by the official dairy laboratory of the region.

\section{Sample Collection and $\mathrm{pH}$ Determination}

On each farm the following samples were collected in sterile containers following aseptic sampling procedures. 1) Bulk-tank milk was obtained at the upper opening of the tank after several minutes of stirring to ensure homogeneity; 2) pooled feces from 3 randomly selected, apparently healthy, lactating cows was taken directly from the rectum; 3) silage, both grass and corn, was sampled from the middle and lower parts of the silage storage container (bunker, trench, or bag).

All samples (98 milk samples, 97 fecal samples, and 83 silage samples) were transported to the laboratory under refrigeration, and all analyses were performed within $24 \mathrm{~h}$ of sampling.

In addition, silage $\mathrm{pH}$ was determined at 3 locations in the silage container (upper, middle, lower) using a portable $\mathrm{pH}$ meter with penetration electrode (Hanna Instruments, Woonsocket, RI) with an accuracy of \pm 0.02 $\mathrm{pH}$ units.

\section{Isolation and Identification of Listeria Species}

Listeria spp. were determined as described by Menéndez et al. (1997). Twenty-five grams of sample was transferred to a flask containing $225 \mathrm{~mL}$ of FDA Listeria enrichment broth (Merck, Darmstadt, Germany) and incubated for $48 \mathrm{~h}$ at $30^{\circ} \mathrm{C}$. After enrichment, samples were plated onto PALCAM (polymixin B sulfate, acriflavine $\mathrm{HCl}$, lithium chloride, ceftazidime, aesculin medium) agar (Merck) and incubated for $72 \mathrm{~h}$ at $37^{\circ} \mathrm{C}$. Morphologically typical black colonies (tellurite-positive) with a black halo (esculin hydrolysis) were confirmed as Listeria on the basis of the catalase reaction with $3 \%$ $\mathrm{H}_{2} \mathrm{O}_{2}$, motility at $25^{\circ} \mathrm{C}$, and sheep blood hemolysis, using the overlay technique and the API Listeria kit (bioMérieux, Marcy l'Etoile, France).

\section{Data Analysis}

Data were analyzed using Excel (Microsoft Corp., Redmond, WA) and the statistical software package SPSS 12.0 (SPSS Inc., Chicago, IL) with the aim of detecting differences between farms with Listeria spp. (or L. monocytogenes) in milk, and farms without Listeria in milk. Categorical variables were compared by $\chi^{2}$ tests and quantitative variables by Student-Fischer $t$-tests (normally distributed data as indicated by Shapiro-Wilk test, $P \geq 0.05$ ) or Mann-Whitney $U$-tests (nonnormally distributed data). For identification of risk factors, odds ratios (OR) and corresponding confidence intervals (CI) were calculated. Statistical significance was indicated by $P \leq$ 0.05 (Doménech, 2003).

\section{RESULTS AND DISCUSSION}

\section{Listeria Prevalences in Milk}

Listeria spp. were detected in $16.3 \%$ of bulk-tank milk samples (Table 1), a greater prevalence than the previously reported $4.1 \%$ in Finland (Husu, 1990), 8.3\% in Ireland (Rea et al., 1992), 10.4\% in the United States (Van Kessel et al., 2004), and $12.4 \%$ in Canada (Farber et al., 1988).

Listeria innocua was detected in milk from $7.1 \%$ of farms, similar to other studies that reported prevalence ranging from 2.3\% in Sweden (Waak et al., 2002), 3.4\% in Ireland (Rea et al., 1992), and 9.7\% in Canada (Farber 
Table 1. Prevalence of different Listeria species in bulk-tank milk, feces, and silage on 98 Galician dairy farms

\begin{tabular}{|c|c|c|c|c|c|c|}
\hline \multirow[b]{2}{*}{ Listeria species } & \multicolumn{2}{|l|}{ Milk } & \multicolumn{2}{|c|}{ Feces } & \multicolumn{2}{|c|}{ Silage } \\
\hline & $\begin{array}{c}\text { Positive } \\
\text { samples, n (\%) }\end{array}$ & $95 \% \mathrm{CI}^{1}$ & $\begin{array}{c}\text { Positive } \\
\text { samples, n (\%) }\end{array}$ & $95 \% \mathrm{CI}$ & $\begin{array}{c}\text { Positive } \\
\text { samples, n (\%) }\end{array}$ & $95 \%$ CI \\
\hline L. monocytogenes & $6(6.1)$ & $1.4-10.8$ & $9(9.3)$ & $3.5-15.1$ & $5(6.0)$ & $0.9-11.1$ \\
\hline L. innocua & $7(7.1)$ & $2.0-12.2$ & $22(22.7)$ & $14.4-31.0$ & 16 (19.3) & $10.8-27.8$ \\
\hline L. welshimeri & $1(1.0)$ & $0.0-5.6$ & $4(4.1)$ & $1.1-10.2$ & $4(4.8)$ & $1.2-11.9$ \\
\hline L. grayi & $2(2.0)$ & $0.3-7.2$ & $4(4.1)$ & $1.1-10.2$ & $2(2.4)$ & $0.3-8.4$ \\
\hline L. ivanovii & - & - & $1(1.0)$ & $0.0-6.5$ & - & - \\
\hline L. seeligeri & - & - & - & - & $1(1.2)$ & $0.0-6.5$ \\
\hline Total & $16(16.3)$ & $8.9-23.6$ & $40(41.2)$ & $31.4-50.9$ & 28 (33.7) & $23.5-43.9$ \\
\hline
\end{tabular}

${ }^{1} 95 \% \mathrm{CI}=$ confidence interval of odds ratio.

et al., 1988). Listeria monocytogenes was found in $6.1 \%$ of tanks, greater than the previously reported $1 \%$ in Sweden (Waak et al., 2002), 1.3\% in Canada (Farber et al., 1988), 2.2\% in Finland (Husu, 1990), 4.9\% in Ireland (Rea et al., 1992), 4.1\% in the United States (Rohrbach et al., 1992), and $4.6 \%$ in the United States (Jarayao and Henning, 2001), although similar to $6.5 \%$ in a recent study in the United States (Van Kessel et al., 2004). Hassan et al. (2000) analyzed milking equipment filters and found an L. monocytogenes prevalence of $12.6 \%$. This was partly attributable to concentrations of the bacteria in the filter and dilution in the tanks, and to the lack of appropriate methods for isolating Listeria spp. from raw milk (Farber et al., 1988; Hassan et al., 2000). Reported prevalence of Listeria spp. varied greatly from study to study, possibly reflecting differences among regions or because of among-study differences in sample type (tank milk, filters) or analytical methods (Van Kessel et al., 2004). The prevalence of other Listeria species in milk samples was negligible: $L$. grayi in $2.0 \%$ of farms and L. welshimeri in $1.0 \%$. These values approximate the 1.3\% reported by Farber et al. (1988) for L. welshimeri.

Analysis of bulk-tank milk is important in view of the ability of Listeria spp. to survive at refrigeration temperatures and because of the techniques used to manufacture certain products from raw milk. For example, L. monocytogenes was detected in $6.4 \%$ (Rudolf and Scherer, 2001) and 4.9\% (Pak et al., 2002) of samples of cheese produced from raw milk; in the former study, $L$. innocua was detected in $10.6 \%$ of samples and L. seeligeri in 1.2\% (Rudolf and Scherer, 2001). In addition, Listeriacontaminated milk constitutes a risk for industrial dairy plants, for which raw milk is one of the principal sources of contamination (Menéndez et al., 1997).

\section{Listeria Prevalence in Silage and Feces}

Listeria spp. were detected in $32.2 \%$ of the 180 samples of silage and feces. This percentage is lower than the 77.8\% obtained by Sanaa et al. (1996), but similar to the
30.6\% obtained by Husu (1990). These values confirm the importance of environmental sources of Listeria spp. in dairy farms. In $7.2 \%$ of silage samples and $3.1 \%$ of fecal samples, more than 1 species of Listeria was detected. Reported prevalences of Listeria spp. in feces of healthy animals vary widely, apparently because of differences in sampling procedures and analytical methods (Husu, 1990).

Table 1 shows the prevalence of different Listeria spp. in milk, feces, and silage. Listeria spp. were detected in $41.2 \%$ of the 97 fecal samples analyzed, greater than the reported 8\% in Sweden (Unnerstad et al., 2000) and 9.6\% in Finland (Husu, 1990), but lower than the $81 \%$ from France (Sanaa et al., 1996). The presence of Listeria spp. in the feces of clinically healthy animals suggests that feces from such animals may be a source of contamination of milk (Unnerstad et al., 2000). We detected Listeria innocua in $22.7 \%$ of the samples, a greater prevalence than the $2 \%$ obtained in Sweden (Unnerstad et al., 2000) and the $4.6 \%$ in Finland (Husu, 1990). Listeria monocytogenes was present in $9.3 \%$ of our samples, similar to the 6\% obtained by Unnerstad et al. (2000) and 6.7\% obtained by Husu (1990), but lower than the value of 39\% obtained by Sanaa et al. (1996). Listeria welshimeri was present in $4.1 \%$ of the samples, greater than the $0.2 \%$ obtained by Husu (1990). In addition, we detected L. grayi in $4.1 \%$ of our samples and $L$. ivanovii in $1.0 \%$. Neither of these species was cited in the previous studies. Listeria seeligeri was not detected in fecal samples, as in previous studies (Unnerstad et al., 2000); Husu (1990) did detect this species, but only in $0.1 \%$ of samples.

We detected Listeria spp. in $33.7 \%$ of silage samples, a value intermediate between $22.7 \%$ in Finland (Husu, 1990) and 62\% in France (Sanaa et al., 1996). Listeria monocytogenes was present in $6.0 \%$ of our silage samples, greater than the $3 \%$ obtained by Rea et al. (1992) in Ireland, but lower than the values of $16 \%$ obtained in Finland (Husu, 1990) and 39\% in France (Sanaa et al., 1996). Listeria innocua was detected in $19.3 \%$ of our silage samples, greater than the $6 \%$ obtained by Rea et 
Table 2. Associations between silage characteristics and presence of Listeria spp. in silage on 98 Galician dairy farms

\begin{tabular}{|c|c|c|c|c|}
\hline$\underline{\text { Variable }}$ & $\begin{array}{c}\text { Positive } \\
\text { samples, n (\%) }\end{array}$ & $P$-value ${ }^{1}$ & Odds ratio & $95 \% \mathrm{CI}^{2}$ \\
\hline \multicolumn{5}{|l|}{$\mathrm{pH} \geq 4.5$} \\
\hline $\begin{array}{l}\text { No } \\
\text { Yes }\end{array}$ & $\begin{aligned} 1 / 16 & (6.2) \\
18 / 61 & (29.5)\end{aligned}$ & 0.05 & \multirow[t]{2}{*}{6.28} & \multirow[t]{5}{*}{$0.77-51.16$} \\
\hline Storage & & & & \\
\hline Bunker silo & $9 / 35 \quad(25.7)$ & \multirow{3}{*}{0.96} & 1.00 & \\
\hline Bag & $3 / 12(25.0)$ & & 0.97 & \\
\hline Unlined trench & $8 / 28(28.6)$ & & 1.11 & \\
\hline
\end{tabular}

${ }^{1}$ Significance $(P \leq 0.05)$ of $\chi^{2}$ test.

${ }^{2} 95 \% \mathrm{CI}=$ confidence interval of odds ratio.

al. (1992). Other Listeria species were detected in silage with lower prevalence: $4.8 \%$ for $L$. welshimeri, $2.4 \%$ for $L$. grayi, and $1.2 \%$ for $L$. seeligeri.

The $\mathrm{pH}$ of silage samples from which Listeria spp. were isolated ranged from 4.47 to 6.97 , a different range from those observed in other studies: 3.8 to 5.2 in Rea et al. (1992) and 5.78 to 5.89 in Ryser et al. (1997). The range obtained in the present study was more consistent with the lower $\mathrm{pH}$ limit of 4.5 for multiplication of Listeria spp. (Sanaa et al., 1993). This $\mathrm{pH}$ cut-off was selected in view of previous reports indicating that insufficient acidification of silage may favor the growth of Listeria spp., notably if $\mathrm{pH}$ is $>4.0$ (Sanaa and Ménard, 1994; Ryser et al., 1997) or 5.5 (Low and Donachie, 1997). The presence of Listeria spp. in silage was associated $(P=$ 0.05 ) with silage $\mathrm{pH}$ (Table 2): when the $\mathrm{pH}$ was $\geq 4.5$, the risk of presence of Listeria was increased $(\mathrm{OR}=6.28)$. Silage storage method (concrete bunker silo, unlined trench, bagging) did not affect the presence of Listeria spp. (Table 2).

\section{Relationship Between Listeria Presence in Milk, Silage, and Feces}

Table 3 shows associations between the presence of Listeria spp. in milk, silage, and feces. In previous studies the proportion of farms with Listeria spp. present in all 3 sample types was as high as 50\% (Rea et al., 1992). According to Sanaa and Ménard (1994), the presence of L. monocytogenes in silage, feces, or both increases the risk of presence in milk by a factor of 20 , a finding we could not support.

Of the farms with Listeria spp. present in silage, 28.6\% showed Listeria spp. in milk. Sanaa et al. (1993) reported that $8.5 \%$ of farms Listeria spp.-positive cases had silage with $\mathrm{pH}>4$, and $68.7 \%$ did not use individual towels to clean udders before milking; we noted that the risk of contamination increased in farms with low-quality silage and with poor milking practices. Of the farms with Listeria spp. in feces, $24.3 \%$ showed Listeria spp. in milk, close to the $24.4 \%$ obtained by Husu (1990). Other studies have likewise considered fecal material as a potential source of exogenous contamination of milk, principally due to poor hygiene practices during milking (Sanaa et al., 1996). Of the farms in the present study with Listeria spp. in silage, $38.1 \%$ showed Listeria spp. in feces, less than the $61.5 \%$ obtained by Husu (1990). This value (38.1\% prevalence of Listeria spp. in feces, on farms with Listeria in silage) was similar to the value obtained for farms without Listeria in silage (39.3\%; Table 3). Similarly to Husu (1990), we found no association $(P=0.92)$ between silage consumption and Listeria contamination of the feces of clinically healthy animals, although Ryser et al. (1997) found a similar association.

\section{Risk Factors for the Presence of Listeria Species in Milk}

Table 4 summarizes the results of associations between potential risk factors and the presence of Listeria spp. in milk. However, as pointed out by Hassan et al. (2001), interpretation of the effect of a given variable on the presence of Listeria should be based not solely on the presence or absence of a statistically significant association, but also on an understanding of the microorganism's biology.

With regard to general housing conditions, we considered the influence of ventilation and cleanliness on the presence of microorganisms in milk. We found that ventilation and cleanliness were not related $(P>0.05)$ to the presence of Listeria in milk. In $96.8 \%$ of the farms, the managers reported that teats were cleaned before placing the milking cups; despite this, Listeria spp. were detected in milk in $16.5 \%$ of farms. This might be because teat cleaning was not always adequately done, or because of the influence of other risk factors.

Protecting the milk from environmental contamination in stall milking systems is more difficult than in parlor milking systems, so that BC tends to be greater (Hassan et al., 2001), as was the case in the present 
Table 3. Associations between presence of Listeria spp. in milk, silage, and feces on 98 Galician dairy farms

\begin{tabular}{|c|c|c|c|c|}
\hline & $\begin{array}{l}\text { Listeria-positive milk } \\
\text { samples, } \mathrm{n}(\%)\end{array}$ & $P$-value ${ }^{1}$ & Odds ratio & $95 \% \mathrm{CI}^{2}$ \\
\hline $\begin{array}{l}\text { Listeria spp. in silage } \\
\text { No } \\
\text { Yes }\end{array}$ & $\begin{array}{ll}8 / 62 & (12.9) \\
6 / 21 & (28.6)\end{array}$ & 0.10 & 2.70 & 0.81-8.99 \\
\hline $\begin{array}{l}\text { Listeria spp. in feces } \\
\text { No } \\
\text { Yes }\end{array}$ & $\begin{array}{ll}7 / 60 & (11.7) \\
9 / 37 & (24.3)\end{array}$ & 0.10 & 2.43 & $0.82-7.23$ \\
\hline & $\begin{array}{l}\text { Listeria-positive fecal } \\
\text { samples, n }(\%)\end{array}$ & & & \\
\hline $\begin{array}{l}\text { Listeria spp. in silage } \\
\text { No } \\
\text { Yes }\end{array}$ & $\begin{aligned} 24 / 61 & (39.3) \\
8 / 21 & (38.1)\end{aligned}$ & 0.92 & 0.95 & $0.34-2.63$ \\
\hline
\end{tabular}

${ }^{1}$ Significance $(P \leq 0.05)$ of $\chi^{2}$ test.

${ }^{2} 95 \%$ CI $=$ confidence interval of odds ratio.

study (pipeline average BC: $48 \times 10^{3} \mathrm{cfu} / \mathrm{mL}$ vs. parlor average: $32 \times 10^{3} \mathrm{cfu} / \mathrm{mL}$ ). The risk of milk contamination by Listeria spp. was almost 3-fold greater on farms having a pipeline stall milking system $(P=0.01, \mathrm{OR}=2.87)$ than farms with parlor milking systems, as in previous studies (Rohrbach et al., 1992). Only $40.2 \%$ of farmers correctly identified cows with mastitis, and on these farms the probability of Listeria spp. in milk was lower $(\mathrm{OR}=0.44 ; P=0.17)$, but not different from farms with farmers who could not identify cows with mastitis. Al- though Listeria spp. are isolated with rather low prevalence from the mammary glands (i.e., they are infrequently associated with mastitis; Rea et al., 1992; Rohrbach et al., 1992; Sanaa et al., 1996), the risk of milk contamination from cows with mastitis due to Listeria exists. In addition, following an appropriate order of milking reduces the likelihood of bacterial transmission between animals and of contamination of the milking equipment, and thus, reduces the probability of appearance of Listeria spp. in the bulk tank. The risk of contami-

Table 4. Associations between management practices and presence of Listeria spp. in bulk-tank milk on 98 Galician dairy farms

\begin{tabular}{|c|c|c|c|c|}
\hline Variable & $\begin{array}{c}\text { Positive } \\
\text { samples, n (\%) }\end{array}$ & $P$-value ${ }^{1}$ & Odds ratio & $95 \% \mathrm{CI}^{2}$ \\
\hline \multicolumn{5}{|c|}{ Stable management } \\
\hline \multicolumn{5}{|c|}{ Ventilation } \\
\hline Reduced & $5 / 23(21.7)$ & 0.44 & 0.63 & $0.19-2.05$ \\
\hline Good & 11/74 (11.9) & & & \\
\hline \multicolumn{5}{|l|}{ Cleanliness } \\
\hline Poor & 6/36 (16.7) & 0.80 & 0.86 & $0.28-2.67$ \\
\hline Good & 9/61 (14.7) & & & \\
\hline \multicolumn{5}{|l|}{ Milking } \\
\hline \multicolumn{5}{|c|}{ Milking system } \\
\hline Parlor & $4 / 40(10)$ & 0.01 & 1.00 & \\
\hline Pipeline & $12 / 42(28.6)$ & & 2.87 & \\
\hline Bucket & $0 / 15(0)$ & & 0 & \\
\hline \multicolumn{5}{|c|}{ Identification of mastitic cows } \\
\hline No & 12/58 (20.7) & 0.17 & 0.44 & $0.13-1.47$ \\
\hline Yes & 4/39 (10.3) & & & \\
\hline \multicolumn{5}{|c|}{ Correct milking order } \\
\hline No & $8 / 25(32)$ & 0.01 & 0.26 & $0.08-0.81$ \\
\hline Yes & 7/65 (10.7) & & & \\
\hline \multicolumn{5}{|c|}{ Forestripping } \\
\hline No & $2 / 20 \quad(10)$ & 0.37 & 2.03 & $0.42-9.79$ \\
\hline Yes & $14 / 76 \quad(18.4)$ & & & \\
\hline \multicolumn{5}{|c|}{ Check that cows lie down after milking } \\
\hline No & $8 / 64(12.5)$ & 0.18 & 2.13 & $0.69-6.56$ \\
\hline Yes & 7/30 (23.3) & & & \\
\hline
\end{tabular}

${ }^{1}$ Significance $(P \leq 0.05)$ of $\chi^{2}$ test.

${ }^{2} 95 \%$ CI $=$ confidence interval of odds ratio. 
nation of milk by Listeria was greater when a correct milking order was not followed $(P=0.01, \mathrm{OR}=0.26)$.

\section{Association Among Listeria Contamination, $S C C$, and $B C$}

Most of the farms had milk SCC $<400 \times 10^{3}$ cells $/ \mathrm{mL}$ (83.9\%), with $34.5 \%$ of farms having $<200 \times 10^{3}$ cell $/ \mathrm{mL}$. On $96.5 \%$ of farms, BC was $<100 \times 10^{3} \mathrm{cfu} / \mathrm{mL}$, and on $42.4 \%$ of farms $<20 \times 10^{3} \mathrm{cfu} / \mathrm{mL}$. Somatic cell counts and $\mathrm{BC}$ were not different $(P>0.64)$ in milk with Listeria than in milk without (SCC: $252 \times 10^{3}$ vs. $250 \times 10^{3}$ cells/ $\mathrm{mL}$; BC: $29 \times 10^{3}$ vs. $26 \times 10^{3} \mathrm{cfu} / \mathrm{mL}$ ).

Considering SCC as a categorical variable $\left(<200 \times 10^{3}\right.$ cells $/ \mathrm{mL}, 200$ to $400 \times 10^{3}$ cells $/ \mathrm{mL}$, and $>400 \times 10^{3}$ cells/ $\mathrm{mL}$ ), the prevalence of Listeria spp. in milk did not vary among the 3 categories $(P=0.32)$, as shown in other studies (Rohrbach et al., 1992; Hassan et al., 2000; Van Kessel et al., 2004). When $\mathrm{BC}$ was considered as a categorical variable $\left(<20 \times 10^{3} \mathrm{cfu} / \mathrm{mL}, 20\right.$ to $100 \times 10^{3} \mathrm{cfu} /$ $\mathrm{mL}$, and $>100 \times 10^{3} \mathrm{cfu} / \mathrm{mL}$ ), the presence of Listeria spp. in milk again showed no significant variation among the 3 categories.

In conclusion, correct practices with respect to silage production and milking are essential for preventing introduction of Listeria into the herd, its spread within the herd, and its entry into milk. More studies are needed to clarify the significance of these risk factors, because only 1 sample was collected at each farm in the current study. The risk of contamination of milk by Listeria spp. increased when animals were fed low-quality silage, notably silage with $\mathrm{pH} \geq 4.5$. The prevalence of Listeria species and $L$. monocytogenes in bulk-tank milk was similar to that reported in previous studies.

\section{REFERENCES}

Cooper, J., and R. D. Walker. 1998. Listeriosis. Microbial food borne pathogens Vet. Clin. North Am. Food Anim. Pract. 14:113-125.

Doménech, J. M. 2003. Fundamentos de Diseño y Estadística. UD 9 : Comparación de dos proporciones. Medidas de asociación y efecto, UD 10: Relación entre dos variables categóricas: Pruebas de $\chi^{2}$, and UD 11. Comparación de dos medias: Pruebas $t$. Signo, Barcelona, Spain.

Farber, J. M., G. W. Sanders, and S. A. Malcolm. 1988. The presence of Listeria spp. in raw milk in Ontario. Can. J. Microbiol. 34:95-100.

Fenlon, D. R., and J. Wilson. 1989. The incidence of L. monocytogenes in raw milk from farm bulk tanks in North-East Scotland. J. Appl. Bacteriol. 66:191-196.

Hassan, L., H. O. Mohammed, and P. L. McDonough. 2001. Farmmanagement and milking practices associated with the presence of $L$. monocytogenes in New York state dairy herds. Prev. Vet. Med. 51:63-73.
Hassan, L., H. O. Mohammed, P. L. McDonough, and R. N. González. 2000. A cross-sectional study on the prevalence of Listeria monocytogenes and Salmonella in New York dairy herds. J. Dairy Sci. 83:2441-2447.

Husu, J. R. 1990. Epidemiological studies on the occurrence of Listeria monocytogenes in the feces of dairy cattle. J. Vet. Med. B. 37:276-282.

Instituto Galego de Estatística. 2005. Explotación do Rexistro de Gando Bovino. http://www.ige.eu/ga/economicas/agro_pesca/rexistro_ bovino/index.htm Accessed Jan. 17, 2005.

Jarayao, B. M., and D. R. Henning. 2001. Prevalence of foodborne pathogens in bulk tank milk. J. Dairy Sci. 84:2157-2162.

Low, J. C., and W. Donachie. 1997. A review of Listeria monocytogenes and listeriosis. Vet. J. 153:9-29.

Menéndez, S., M. R. Godínez, J. L. Rodríguez-Otero, and J. A. Centeno. 1997. Removal of Listeria spp. in a cheese factory. J. Food Safety $17: 133-139$

Pak, S. I., U. Spahr, T. Jemmi, and M. D. Salman. 2002. Risk factors for L. monocytogenes contamination of dairy products in Switzerland, 1990-1999. Prev. Vet. Med. 53:55-65.

Rea, M. C., T. M. Cogan, and S. Tobin. 1992. Incidence of pathogenic bacteria in raw milk in Ireland. J. Appl. Bacteriol. 73:331-336.

Rohrbach, B., F. A. Draughon, P. M. Davidson, and S. P. Oliver. 1992 Prevalence of L. monocytogenes, C. jejuni, Y. enterocolitica, and Salmonella in bulk tank milk: Risk factors and risk of human exposure. J. Food Prot. 55:93-97.

Rudolf, M., and S. Scherer. 2001. High incidence of Listeria monocytogenes in European red smear cheese. Int. J. Food Microbiol. 63:91-98.

Ryser, E., S. M. Arimi, and C. W. Donelly. 1997. Effects of pH on distribution of Listeria ribotypes in corn, hay and grass silage. Appl. Environ. Microbiol. 63:3695-3697.

Sanaa, M., A. Audurier, B. Poutrel, J. L. Menard, and F. Serieys. 1996. Origin of bovine raw milk contamination by Listeria monocytogenes. Pages 84-88 in Symposium on Bacteriological Quality of Raw Milk, IDF. Austria. Int. Dairy Fed., Brussels, Belgium.

Sanaa, M., and J. L. Ménard. 1994. Contamination du lait cru par $L$. monocytogenes: Origines, facteurs de risque, prévention. Rec. Méd. Vet. 170:437-442.

Sanaa, M., B. Poutrel, J. L. Ménard, and F. Serieys. 1993. Risk factors associated with contamination of raw milk by L. monocytogenes in dairy farms. J. Dairy Sci. 76:2891-2898.

Unnerstad, H., A. Romell, H. Ericsson, M. L. Danielsson-Tham, and W. Tham. 2000. Listeria monocytogenes in faeces from clinically healthy dairy cows in Sweden. Acta Vet. Scand. 41:167-171.

Van Kessel, J. S., J. S. Karns, L. Gorski, B. J. McCluskey, and M. L. Perdue. 2004. Prevalence of Salmonella, Listeria monocytogenes, and fecal coliforms in bulk tank milk on US dairies. J. Dairy Sci. 87:2822-2830.

Vázquez-Boland, J. A., M. Kuhn, P. Berche, T. Chakraborty, G. Domínguez-Bernal, W. Goebel, B. González-Zorn, J. Wehland, and J. Kreft. 2001. Listeria pathogenesis and molecular virulence determinants. Clin. Microbiol. Rev. 14:584-640.

Waak, E., W. Tham, and M. L. Danielsson-Tham. 2002. Prevalence and fingerprinting of Listeria monocytogenes strains isolated from raw whole milk in farm bulk tanks and in dairy plant receiving tanks. Appl. Environ. Microbiol. 68:3366-3370.

WHO. 2002. Food safety and foodborne illness. http://www-who.int/ mediacentre /factsheets/fs237/en/ Accessed May 12, 2005.

Wiedmann, M. 2003. An integrated science based approach to dairy food safety: Listeria monocytogenes as a model system. J. Dairy Sci. 86:1865-1875.

Winter, P., F. Schilcher, Z. Bagò, D. Schoder, M. Egerbacher, W. Baumgartner, and W. Wagner. 2004. Clinical and histopathological aspects of naturally occurring mastitis caused by Listeria monocytogenes in cattle and ewes. J. Vet. Med. 51:176-179. 